\title{
Evaluate the Complication of Kerosene Ingestion
}

Dr. Saida Binte Rahman ${ }^{1 *}$, Dr. Habibur Rahman ${ }^{2}$, Dr. Shamima Sultana ${ }^{3}$, Dr. Shamim Ferdous Khan ${ }^{4}$, Dr. Salma Hossain $^{5}$, Dr. Sajani Islam Snigdha ${ }^{6}$

${ }^{1}$, Assistant Professor, Department of Paediatrics, Mugda Medical College and Hospital, Dhaka, Bangladesh

${ }^{3}$ Medical Officer, Department of Paediatrics, Dhaka Medical College and Hospital, Dhaka, Bangladesh

${ }^{4}$ Senior Consultant, Department of Paediatrics, Kuwet Bangladesh Maitry Govt. Hospital, Dhaka, Bangladesh

${ }^{5}$ Assistant Professor, Department of Paediatrics, Ashiyan Medical College, Dhaka, Bangladesh

${ }^{6}$ Assistant Professor, Department of Paediatrics, Shuhrawardi Medical College Hospital, Dhaka, Bangladesh

DOI: $10.36347 /$ sjams.2021.v09i04.023

| Received: 12.03.2021 | Accepted: 18.04.2021 | Published: 27.04.2021

*Corresponding author: Dr. Saida Binte Rahman

Abstract

Original Research Article

Background: This prospective study was conducted to evaluate the complication of kerosene ingestion of young children with kerosene poisoning with or without antibiotics. A total 50 (33 male and 17 female) children of age 1 year to 5 years were selected. Those who fulfilled the inclusion criteria were included in the study. In addition to supportive management all odd number got antibiotic injectable and even number got no antibiotic. X-ray chest was done in all patients, pulse oximetry and complete blood count was also done. The patients were seen during admission and followed up after 6 hours, after 12 hours, 18 hours, 24 hours and 48 hours and if patients were clinically improved, advised to return for follow up after 7 days, characteristic of both the groups on admission in respect of mean R/R mean SP02 wheeze, ronchi, creps, fever were almost similar and X-ray finding showed abnormality in almost same percentage in both group. Improvement was followed up daily during hospital stay and after 7 days of ingestion. Most cases in both group improved after 24 hours, patients were considered improved clinically \pm radiologically. This study shows there in no statistically significant difference in outcome of both groups. So in this study it was seen that chemical pneumonitis in Kerosene poisoning whether treated with or without antibiotic recovered in the same fashion.

Keywords: Pneumonitis, Kerosene poisoning, hydrocarbon ingestion.

Copyright $(\mathcal{C} 2021$ The Author(s): This is an open-access article distributed under the terms of the Creative Commons Attribution 4.0 International License (CC BY-NC 4.0) which permits unrestricted use, distribution, and reproduction in any medium for non-commercial use provided the original author and source are credited.

\section{INTRODUCTION}

Kerosene is a hydrocarbon. Hydrocarbons ranked sixth in substances most frequently involved in human exposures reported to the American Association of poison control centers National Data Collection System in 1989[1]. Accidental kerosene poisoning continues to be a major problem in children and is prevalent mostly in low socioeconomic group. Frequent use of kerosene oil, an easily available cheap fuel, for cooking in rural areas and urban slums predispose frequent accidental kerosine poisoning among children $[2,3]$.

Poison is a substance capable of producing damage or dysfunction in the body by its chemical activity. It can enter the body in various ways to produce general or local effects. All cases of poisoning those results from accidental use of drugs by children due to ignorance $\&$ curiosity are known as accidental or non-intentional poisoning. Poisoning is a qualitative term used to define the potential of a chemical substance in acting adversely or deleteriously on the body [4-7]. Kerosene poisoning by and large is an accidental or non-intentional poisoning in children.

Hydrocarbons represent a diverse group of substance and several classification systems have been used to describe them. Probably the most useful means of classifying hydrocarbons is with respect to their clinical effects. Two groups my by described (1) Hydrocarbons which are easily aspirated following ingestion and (2).

Toxicity of any hydrocarbon is directly related to their physical properties, specifically the viscosity, volatility and surface tension. Highly volatile substance with low viscosity are more likely to be inhaled or aspirated into respiratory systems. The viscosity of kerosene is lower (<60SSU)[8]. So kerosene ingestion has higher chance of aspiration.

Aspiration pneumonitis is the most common complication of hydrocarbon ingestion, followed by central nervous system and cardiovascular complications. Though some cases may be 
Saida Binte Rahman et al; Sch J App Med Sci, Apr, 2021; 9(4): 601-604

asymptomatic, presentation is mostly of acute respiratory distress, as a result of chemical pneumonitis and bronchospasm. Respiratory symptoms generally begin in the first few hours after exposure and usually resolves in 2-8 days [9]. Besides pulmonary complication, there may central nervous system depression, tachycardi dysrythmi autonomic dysfunction, skin eruptions [10].

The routine use of antibiotic is not recommended, the occurrence of secondary infection of affected lung can readily be detected by reappearance of fever on 3rd to 5th day after ingestion.36 Anas et al. established guidelines for management of patients with hydrocarbon ingestion and showed that prophylactic antibiotics are not routinely prescribed [11].
Many controversies surround the proper management of exposure. Issues include indication and preferred method for gastric decontamination, use of oil based cathartics' and use of steroids or antibiotics [11].

\section{OBJECTIVE \\ General objective}

- To evaluate the complication of kerosene ingestion.

\section{Specific objective}

- To see the clinical findings of ingestion of kerosine poisoning with and without antibiotics

\section{Methodology}

\begin{tabular}{|l|l|}
\hline Type of study & It was a Prospective randomized control trial study. \\
\hline Place of study & Department of Paediatrics of Dhaka Medical College Hospital, Dhaka. \\
\hline Study period & March 2007- January 2007 \\
\hline Study population & Total population of the study was 50 \\
\hline Sampling technique & Non-probability purposive sampling method \\
\hline
\end{tabular}

\section{Selection Criteria \\ Inclusion criteria}

- Patients with history of kerosene ingestion and presented with cough, fever, respiratory distress +positive finding on chest X-ray.

\section{Exclusion criteria}

- Children with ingestion of kerosene but previously suffering from pneumonia. Br. Asthma, Bronchiolitis, Heart failure.

- Children already getting antibiotics due to any illness.

\section{Study procedure and data collection}

Children who will fulfill the inclusion criteria will be admitted in the indoor department of any of the medical unit of department of paediatrics of Dhaka
Medical College Hospital. After admission, details history will be recorded. History will be related to when kerosene was ingested, how much ingested and what problems arise after ingestion. Then all the included children will be first undergo physical examination relating to temperature, respiratory rate, pulse rate, pulse oximetry and thorough examination of respiratory system.

\section{Statistical Analysis}

Statistical analysis was done by computer based software programme SPSS version 12; Chi square test was done to analysis the data. $\mathrm{P}$ value $<0.05$ was considered as significant.

\section{RESUlTS}

Table-I: Distribution of patients according to age (year)

\begin{tabular}{|l|l|l|l|l|l|}
\hline Groups & $\mathbf{N}$ & $\begin{array}{l}\text { Minimum (Age in } \\
\text { year) }\end{array}$ & $\begin{array}{l}\text { Maximum } \\
\text { (Age in year) }\end{array}$ & Mean (Age in year) & $\begin{array}{l}\text { Std. } \\
\text { Deviation }\end{array}$ \\
\hline Case & 25 & 1.00 & 4.50 & 2.9600 & 1.05987 \\
\hline Control & 25 & 2.00 & 7.00 & 4.3600 & 1.46856 \\
\hline
\end{tabular}

The table I shows mean age of case group were $2.96( \pm 1.05)$ mean age of control group were $(4.36+1.46)$.

Table-II: Distribution of patients according to sex

\begin{tabular}{|l|l|l|l|}
\hline \multirow{2}{*}{ Groups } & Sex & \multirow{2}{*}{ Total } \\
\cline { 2 - 3 } & Male & Female & \\
\hline Case & $17(68)$ & $8(32)$ & $25(100)$ \\
\hline Control & $16(64)$ & $9(36)$ & $25(100)$ \\
\hline Total & 33 & 17 & 50 \\
\hline
\end{tabular}


Saida Binte Rahman et al; Sch J App Med Sci, Apr, 2021; 9(4): 601-604

Table II shows in case group 17 were male and were female.

8 were female and in control group 16 were male and 9

Table -III: Distribution of patients according to Outcome of Cough after 7 days

\begin{tabular}{|l|l|l|l|l|l|}
\hline \multirow{2}{*}{ Group } & \multicolumn{2}{|l|}{ Outcome of Cough after 7 Days } & \multirow{2}{*}{$\mathbf{x}^{2}$ value } & $\begin{array}{l}\mathbf{p} \\
\text { value }\end{array}$ \\
\cline { 2 - 4 } & Improved & Not Improved & Total & & \multirow{2}{*}{0.166} \\
\hline Case & $22(88)$ & $3(12)$ & $25(100)$ & 0.684 \\
\hline Control & $21(84)$ & $4(16)$ & $25(100)$ & 50 & \\
\hline Total & 43 & 7 & 50 & \\
\hline
\end{tabular}

Statistical analysis with Chi square test shows non-significant result $(\mathrm{X} 2=0.166, \mathrm{P}=0.68)$

Table III shows outcome of cough after 7 days, in case group improved 22 not improved 3 and in control group improved 21 and not improved 4.

Table-IV: Distribution of patients according to Outcome of Fever after 7 days

\begin{tabular}{|c|c|c|c|c|c|}
\hline \multirow[b]{2}{*}{ Group } & \multicolumn{3}{|c|}{ Outcome of Fever after 7 days } & \multirow{2}{*}{$\begin{array}{l}\mathrm{x}^{2} \\
\text { value }\end{array}$} & \multirow[b]{2}{*}{$p$ value } \\
\hline & Improved & $\begin{array}{l}\text { Not } \\
\text { Improved }\end{array}$ & Total & & \\
\hline Case & $22(88)$ & $3(12)$ & $25(100)$ & \multirow{3}{*}{0.222} & \multirow{3}{*}{0.637} \\
\hline Control & $23(92)$ & $2(8)$ & $25(100)$ & & \\
\hline Total & 45 & 5 & 50 & & \\
\hline
\end{tabular}

Statistical analysis with Chi square test shows non-significant result $\left(X^{2}=0.222, P=0.637\right)$

Figure shows outcome of fever after 7 days, in case group improved 22 not improved 3 and in control group improved 23 and not improved 2

Table-V: Distribution of patients according to Outcome of creating difficulty after 7 days

\begin{tabular}{|c|c|c|c|c|c|}
\hline \multirow[b]{2}{*}{ Group } & \multicolumn{3}{|c|}{ Outcome of Breathing difficulty after 7 days } & \multirow{2}{*}{$\begin{array}{l}\mathrm{x}^{2} \\
\text { value }\end{array}$} & \multirow[b]{2}{*}{ p value } \\
\hline & Improved & $\begin{array}{l}\text { Not } \\
\text { Improved }\end{array}$ & Total & & \\
\hline Case & 25 & 0 & 25 & \multirow{3}{*}{0.000} & \multirow{3}{*}{1.000} \\
\hline Control & 25 & 0 & 25 & & \\
\hline Total & 50 & 0 & 50 & & \\
\hline
\end{tabular}

Statistical analysis with Chi square test shows - non significant result $\left(\mathrm{X}^{2}=0.000, \mathrm{P}=1.000\right)$

Table-VI: Distribution of patients according to Outcome of Cyasnosis after 7 days

\begin{tabular}{|l|l|l|l|l|l|}
\hline \multirow{2}{*}{ Group } & \multicolumn{2}{|l|}{ Outcome of Cyasnosis difficulty after 7 days } & \multirow{2}{*}{$\begin{array}{l}\mathbf{x}^{2} \\
\text { value }\end{array}$} & \multirow{2}{*}{ p value } \\
\cline { 2 - 4 } & Improved & Not Improved & Total & & \\
\hline Case & $25(50)$ & $0(0)$ & $25(100)$ & & \multirow{2}{*}{1.087} \\
\hline Control & $25(50)$ & $0(0)$ & $25(100)$ & 0.297 \\
\hline Total & 50 & 0 & 50 & & \\
\hline
\end{tabular}

Statistical analysis with Chi square test shows - non significant result $\left(\mathrm{X}^{2}=1.087, \mathrm{P}=0.297\right)$

Table-VII: Distribution of patients according to Outcome of temperature after 7 days

\begin{tabular}{|l|l|l|l|l|l|}
\hline \multirow{2}{*}{ Group } & \multicolumn{2}{|l|}{ Outcome of temperature after 7 days } & \multirow{2}{*}{$\mathbf{X}^{2}$ value } & \multirow{2}{*}{ p value } \\
\cline { 2 - 4 } & Improved & Not Improved & Total & & \multirow{2}{*}{0.222} \\
\hline Case & $23(92)$ & $2(8)$ & $25(100)$ & \multirow{2}{*}{0.637} \\
\hline Control & $22(88)$ & $3(12)$ & $25(100)$ & \multirow{2}{*}{0.22} & \\
\hline Total & 45 & 5 & 50 & & \\
\hline
\end{tabular}

Statistical analysis with Chi square test shows non-significant result $(\mathrm{X} 2=0.222, \mathrm{P}=0.637)$

Table VII shows outcome of Temperature after 7 days, in case group improved 23 not improved 2 and in control group improved 22 and not improved 3. 
Saida Binte Rahman et al; Sch J App Med Sci, Apr, 2021; 9(4): 601-604

Table-VIII: Distribution of patients according to outcome of $X$ ray findings after 7 days

\begin{tabular}{|l|l|l|l|l|l|}
\hline \multirow{2}{*}{ Group } & \multicolumn{2}{|l|}{ Outcome of Xray findings after 7 days } & \multirow{2}{*}{ 2 value } & \multirow{2}{*}{ p value } \\
\cline { 2 - 4 } & Improved & Not Improved & Total & & \multirow{2}{*}{} \\
\hline Case & $22(88)$ & $3(12)$ & $25(100)$ & & \multirow{2}{*}{0.684} \\
\hline Control & $21(84)$ & $4(16)$ & $25(100)$ & 0.166 & \\
\hline Total & $43(86)$ & $7(14)$ & 50 & & \\
\hline
\end{tabular}

Statistical analysis with Chi square test shows non-significant result $\left(X^{2}=0.166, P=0.684\right)$

Table VIII shows outcome of radiological improvement after 7 days, in case group improved 3 and in control group improved 21 and not improved 4.

\section{DISCUSSION}

In a study it is established that there is no significant difference in the median duration of hospital stay between the group that received prophylactic antibiotics and the one that did not and their findings do not support the use of prophylactic antibiotics in patients with hydrocarbon ingestion [12]. In our study, several variables are noted such as age, amount of ingestion. Variable clinical findings after ingestion, pulse oximetry, complete blood count and chest X-ray finding. In general kerosene has a bad taste. So large volumes are rarely ingested and ingestion of even $1 \mathrm{ml}$ kerosene oil is significantly related to pulmonary complication [11]. In our study, mean amount of kerosene ingestion was $4.3 \mathrm{ml}$. Antibiotic was given in $50 \%$ patients who were considered as cases. The drug was Injection Ampicillin $100 \mathrm{mg} / \mathrm{kg} /$ day in 4 divided doses. $50 \%$ patients were not given any antibiotic. Follow up was given according to sign, symptoms of structured questionnaire during admission, after 6 hours, after 12 hours after 24 hours and after 48 hours. All patients were done chest X-ray 6 hours after ingestion of Kerosene; patients were discharged after 48 hours and asked for follow up visit after 7 days for clinical improvement and radiological improvement. In this study, 12 cases were drop out, 5 cases did not tum out in regular follow up after 7 days, 2 cases left hospital on DORB. Check X-ray was not possible to do in 5 cases of those who came for follow up. As our outcome was either clinical or radiological cure it did not hamper the study. The result showed no significant difference in with antibiotic and no antibiotic group. Within 48 hours all patients (both case and control) sign symptom improved and after 7 days all children were quite normal and check X-ray showed radiological improvement in both case and control groups.

\section{CONCLUSION}

This study shows there in no statistically significant difference in outcome of both group. So in this study it was seen that chemical pneumonitis in Kerosene poisoning whether treated with or without antibiotic recovered in the same fashion.

\section{REFERENCE}

1. Litovitz T. Hydrocarbon ingestions. Entechnology. 1983 Mar;62(3):142-7.

2. Ellis JB, Krug Roberston J, Hay IT, Macintyre U. Paraffin ingestion-the problem. S Afr Med J. 1994;84:727-730.

3. Lifshitz M, Gavrilov V. Acute poisoning in children. IMAJ. 2000; 2:504-506.

4. Machado B, Cross K, Snodgrass W. Accidental hydrocarbon ingestion cases telephoned to a regional poison center. Ann Emerg Med. 1988; 17:804-807

5. Reed RP, Conradie FM. The epidemiology and clinical features of paraffin (kerosene) poisoning in rural African children. Ann Trop Paediatr. 1997; 17:49-55.

6. Nagi NA, Abdulallah ZA. Kerosene poisoning in children in Iraq. Postgraduate medical journal. 1995 Jul 1;71(837):419-22.

7. Ellis JB, Krug · Roberston J, Hay IT, MacIntyre U. Paraffin ingestion the problem. SAfr Med J. 1994; 84:727- 730

8. http://www.chop.edu/consumer/jsp/division/generic .jsp?id= 72616

9. Nwafor Obinna C, Kerosine poisoning in a child: A case report; medikka. Journal of the university of Nigeria medical students; 1-1 643;1-4.

10. Patel Al, Shaikh W pateI I-IL, Deshmukh D. Kerosine poisoning-varied systemic manifestations a case report. JAPI. 2004; 52.

11. Prasad R, Muthusami S, Pandey N. Kerosene poisoning pediatric oncall. John P, Jimenez MD, Richard G. pulmonary complications following furniture polish ingestion, a report of 21 cases.98: 2 323-333. 